\title{
Kesultanan Banten: \\ Amsterdam van Java yang Makmur Berkat Pertanian
}

\author{
Ayang Utriza Yakin \\ Dosen Sekolah Pascasarjana UIN Jakarta
}

$\begin{array}{ll}\text { Judul buku } & : \text { Banten: Sejarah dan Peradaban abad X-XVII } \\ \text { Penulis } & : \text { Claude Guillot } \\ \text { Jumlah Halaman } & : 430 \\ \text { Penerbit } & : \text { KPG, Jakarta } \\ \text { Cetakan } & : \text { Desember 2008 [beredar Januari 2009] } \\ \text { Cetak ulang } & : 2013 \\ \text { ISBN } & : 9789799101440\end{array}$

Pada 1596 Cornelis de Houtman menggambarkannya seperti Amsterdam. Keberhasilan ekonomi lada dan padi Banten mengundang Bangsa Eropa dan Asia datang mencari peruntungan di zamrud khatulistiwa itu.

Puncak keemasan dan kejayaan Banten terletak pada kebijakan ekonomi dan politik penguasa, demikian salah satu hasil kajian sejarawan Prancis Claude Guillot tentang Banten. Memang, kemakmuran Banten berasal dari hasil perdagangan lada dan perniagaan antar bangsa yang telah diletakkan dasarnya oleh para penguasa Hindu-Budha. Pemerintahan Islam melanjutkannya dan mengandalkan lada sebagai sumber utama ekonomi masyarakat dan pemerintah.

Namun, sumber daya alam yang melimpah itu tak selamanya membawa berkah. Lada selalu menjadi sumber utama konflik baik antar masyarakat maupun antara pedagang asing dan penguasa. Bangsa Asia yang lebih dahulu membangun kerjasama dengan Banten secara perlahan tersingkirkan oleh kedatangan bangsa Eropa: Belanda, Inggris, Denmark, dan Prancis. Hubungan ekonomi yang telah lama terjalin dengan Cina, India, Thailand, Filipina, Taiwan, Jepang, dan Vietnam putus akibat praktik monopoli, terutama, oleh Belanda dan Inggris.

Pangeran Arya Ranamanggala, Perdana Menteri Sultan Abul Mafakhir, menerapkan kebijakan baru: menghapuskan perdagangan lada. Ia melarang rakyat Banten menanam dan menjual lada. Bagi yang belum mengetahui, apalagi melanggar kebijakannya, ia tidak segan untuk menghukum, kalau 
perlu, hukum mati. Ia menghentikan ekonomi pasar-bebas, dan menerapkan pengawasan Negara dengan amat ketat. Walau, harga yang harus dibayar dari kebijakan itu cukup mahal berupa perginya para pedagang asing, tetapi kehidupan masyarakat jauh lebih damai.

Negeri penghasil lada menjadi negeri pertanian. Kebijakan itu mencapai masanya di tangan Sultan Ageng. Claude Guillot menggambarkan keberhasilan ini dengan begitu mengagumkan berdasar sumber-sumber yang digali dari khazanah arsip Belanda. Tahun 1659, Sultan Ageng memerintahkan kepala-kepala desa di seluruh Kesultanan Banten untuk menanam kelapa di Untung Jawa, Cisadane, dekat Batavia. 5 ribu orang dikirim untuk mengerjakan maha proyek itu. Hasilnya 5 ribu hektar lahan baru dibuka. Inilah awal transmigrasi besar-besaran di Nusantara.

Ia menerapkan politik pangan yang luar biasa. Pada 1663, ia membangun sungai sepanjang $6 \mathrm{~km}$ antara Tanara dan Pasilian dengan mempekerjakan 5 ribu orang. Sungai ini dibuat agar para penduduk dapat membawa hasil produksi beras mereka dengan mudah dari Pasilian ke Tanara, lalu dari Tanara ke Banten. Pada 1670 dibangun lagi sungai baru antara Pontang dan Tanara sebagai sarana untuk mengangkut beras. Jumlah orang yang menyelesaikan mega proyek ini 26 ribu. Sepanjang sungai yang baru dikerjakan, dibangun juga lumbung padi atau persawahan untuk menanam padi. Pembangunan sungai atau kali itu untuk membangun budaya baru berupa pertanian.

Selama 30 tahun kekuasaanya, menurut Guillot, Sultan Ageng membangun banyak proyek untuk pengembangan pertanian di Banten. Hasil dari pembangunan itu adalah: 30-40 km pembangunan sungai baru, 30-40 ribu hektar lahan persawahan dibuka, ribuan hektar tanah menjadi kebun pohon kelapa, dan transmigrasi 30 ribu orang ke tempat-tempat baru yang belum dihuni. Proyek pertanian ini berhasil. Masyarakat hidup dalam kedamaian dan kemakmuran. Semerbak harum kesejahteraan ini menerbangkan angin khayalan bagi para novelis di Eropa abad ke-17, seperti ditemukan Guillot dalam karya-karya mereka.

Yang menarik, masa keemasan Banten di bawah Sultan Ageng Tirtayasa ini memperlihatkan beberapa pelajaran penting bagi kita:

Pertama, menjadi seorang pemimpin tidaklah tercipta dalam waktu singkat. Tidak asal sulap langsung jadi. Ia lahir dari hasil tempaan yang panjang. Sebelum memerintah Banten, Sultan Ageng menemani kakeknya, Sultan Abul Mafakhir Abdul Kadir, dan ayahnya, Sultan Abul Maali Ahmad, 
dalam pemerintahan. Ia ikut serta dalam memecahkan berbagai persoalan dan masalah politik. Insting politiknya sudah terasah sejak muda. Dihargai oleh para pembesar kerajaan yang menaruh harap besar padanya dan dicintai rakyat yang percaya akan komitmennya menyejahterakan nasib mereka.

Kedua, keberhasilan seorang pemimpin ditopang oleh orang-orang kepercayaan dan para pembantu dekatnya. Sultan Ageng dibantu oleh Perdana Menteri yang amat setia dan kuat: Ki Arya Mangunjaya. Dialah arsitek dan otak keberhasilan pemerintahan Sultan Ageng dalam menjadi stabilitas politik dan keamanan.Ia juga dibantu oleh Menteri Perekonomian yang jitu, dialah Ki Ngabehi Cakradana, orang Cina yang masuk Islam dan punya nama Abdul Gafur. Di tangannyalah, ia menerapkan reformasi ekonomi Banten. Ia menjalin kembali hubungan ekonomi yang telah lama terputus dengan Cina. Membuat kebijakan di pelabuhan Banten yang adil dan tegas. Arsitek kota yang merubah Banten menjadi kota metropolis. Ia tak henti-hentinya membangunekonomi Banten.

Ketiga, keberagamaan pemimpin memengaruhi masyarakat. Sultan Ageng berupaya membantenkan Islam, sementara Sultan Haji ingin mengarabkan Banten. Sultan Ageng menjunjung nilai dan adat setempat, sementara sang anak dihinggapi perasaan inferioritas terhadap kebudayaan luar, sehingga perlu mengadopsinya. Setelah pulang dari Mekkah, Sultan Haji berpakaian ala orang Arab dan memerintahkan masyarakat Banten memakai jubah dan sorban seperti dirinya. Ayahnya resah dengan sikap anaknya yang dinilai menumbuhkan nilai-nilai fundamentalisme. Yang pertama mendapat simpati masyarakat, yang kedua memperoleh antipati.

Banyak hal baru dan pelajaran yang dapat dipetik dari buku ini. Sepanjang sepengetahuan saya, inilah buku terbaik tentang sejarah Banten karena mengungkap banyak hal baru dengan metodologi yang jarang digunakan di Indonesia seperti mazhab Annales Perancis. Kehadiran buku ini bukan saja sumbangsih besar bagi masyarakat Banten, tetapi juga bagi masyarakat Indonesia. Suatu karya yang amat serius dan bukti cinta dan pengabdian dari seorang Perancis untuk Banten agar tidak sekadar menjadi sebuah nama, sebuah cerita. 